\title{
PENINGKATAN KEPRIBADIAN MELALUI PENGUASAAN MATERI AJAR KESELAMATAN SISWA KELAS VII SMP NEGERI 1 SIPAHUTAR. KECAMATAN SIPAHUTAR KABUPATEN TAPANULI UTARA TAHUN PEMBELAJARAN 2019/2020
}

\author{
Ronny Simatupang \\ ${ }^{1)}$ Institut Agama Kristen Negeri Tarutung
}

\begin{abstract}
The study is intended to know the increasing of personalities through the mastery of the student safety materials with hypotheses there is a positive and significant influence between the doctrinal mastery of the safety of the student body, with the population of the entire class vii on the student body of 1 sloutar class 1 person with a sample of 36 samples established by random sampling techniques. Data is collected with a test of 20 items and an numbered numbered 20 items. Based on impact tests obtained coefficient determinations $=36.24 \%$ and fjudges > ftable of $20.30>$ 4.13 at a rate of 0.05 . The results have come to a conclusion there is a positive and significant influence between the doctrinal mastery material on the class vii junior year students' learning personality. Clap district tapanuli northern year 2019/2020. Thus, ha received and ho rejected.
\end{abstract}

Keywords: The student's personality mastery materials teach salvation

\begin{abstract}
ABSTRAK
Penelitian ini bertujuan untuk mengetahui peningkatan kepribadian melalui penguasaan materi keselamatan siswa dengan hipotesis terdapat pengaruh positif dan signifikan antara penguasaan ajaran terhadap keselamatan siswa, dengan populasi seluruh kelas vii pada siswa. Tubuh 1 orang sloutar kelas 1 orang dengan jumlah sampel 36 sampel ditetapkan dengan teknik random sampling. Pengumpulan data dilakukan dengan tes sebanyak 20 item dan berjumlah 20 item. Berdasarkan uji impak diperoleh koefisien determinasi $=36.24 \%$ dan fjudges $>$ ftable sebesar 20.30> 4.13 pada taraf 0,05 . Hasil penelitian menyimpulkan bahwa ada pengaruh yang positif dan signifikan antara materi penguasaan ajaran terhadap kepribadian belajar siswa kelas VII SMP Kabupaten Tapanuli Utara Tahun 2019/2020. Jadi, ha diterima dan ho ditolak.
\end{abstract}

Kata Kunci: Materi penguasaan kepribadian siswa mengajarkan keselamatan

\section{PENDAHULUAN}

Pendidikan adalah usaha yang di sengaja dan terprogram dalam rangka membentuk kepribadian seseorang menuju kedewasaan. Dalam hal ini, sekolah sebagai lingkungan pendidikan atau unit operasional sebagai wujud bentuk kerja 
sama antara pemerintah dengan masyarakat sebagai lembaga khusus yang menggumuli masalah pendidikan dan pengajaran. Untuk mencapai masyarakat yang dinamis dan bermutu, maka sekolah sebagai lembaga pendidikan harus memberikan perhatian besar terhadap pentingnya pendidikan yang berhubungan dengan kepribadian, akhlak,dan spiritual siswa. Pendidikan yang baik tidak lepas dari materi pembelajaran khususnya dalam Pendidikan Agama Kristen. Melalui penyajian materi ajar Pendidikan Agama Kristen diharapkan siswa mampu mengalami transformasi nilai-nilai kehidupan berdasarkan nilai-nilai kristen, yang mengarahkan kepada kepribadian siswa.

Setiap guru PAK harus memiliki pengalaman, pengetahuan yang luastermasuk keterampilan untuk membentuk, membina kepribadian siswa . Materi pembelajaran yang di sampaikan tentang keselamatan tidak lepas dari tujuan tertentu, yaitu untuk melakukan aktivitas penginjilan sekaligus mengajar dan membekali siswa untuk bisa ambil bangian dalam penginjilan. Dalam materi pembelajaran keselamatan diterangkan lebih jauh mengenai Yesus sebagai Juruselamat dunia. Sebagai siswa sering ditemukan minimnya pengetahuan terhadap keselamatan. Keselamatan yang dimaksud adalah keselamatan untuk kehidupan kekal. Dengan materi pembelajaran tentang keselamatan siswa dituntut memahami dan mengerti akan keselamatan yang sebenarnya. Mereka memilih Agama kristen bukan karena dari dasar kemauan dan keinginan sendiri namun oleh karena sifat tradisi turun-temurun dari keluarga. Adanya juga perubahan Iman yang dinamis yang artinya seseorang tidak akan kuatir lagi apa yang akan di alami karena memiliki keyakinan dan iman yang lebih kuat. Adanya kepribadian siswayang memiliki iman mudah terguncang yang mudah di ombang-ambingkan tidak memiliki komitmen yang teguh, tidak peduli dengan arti keselamatan yang sesungguhnya karena mereka tidak mengerti dan tidak menguasai materi tentang keselamatan sehingga mereka tidak mampu membuat suatu statement dalam kehidupan kepribadian siswa. Oleh karena itu pembelajaran yang berhasil apabila yang dikuasai mampu mengubah kepribadian siswa kearah yang lebih baik, dengan demikian dapat dikatakan bahwa disamping memiliki ilmu pengetahuan, penanaman nilai-nilai penting untuk dimiliki juga memiliki kepribadian yang unggul.

Keselamatan bukan berdasarkan perkataan dan perbuatan manusia namun, berdasarkan perkataan yang dilakukan dan di ucapkan Tuhan Yesus sang Juruselamat melalui Firman-Nya yang memiliki dasar Theologis. Dalam Efesus 28-9 dikatakan "sebab kasih karunia kamu di selamatkan oleh Iman, itu bukan hasil usahamu, tetapi pemberian Allah, itu bukan hasil pekerjaanmu; jangan ada orang yang memengahkan diri”. Selain itu juga keselamatan memiliki beberapa aspek menurut Senduk dalam Gernaida mengatakan bahwa aspek keselamatan adalah keselamatan yang berhubungan dengan penebusan, rekonsiliasi, propisiasi, pengampunan, pengorbanan, dan pengudusan. Pada hakekatnya seorang siswa 
membutuhkan perhatian dan kedekatan emosional dari orangtua, teman, lingkungan sosial, maupun dari sekolah. Sebagai pribadi yang berada dalam masa muda yang tergolong pada masa transisi banyak mengalami gejolak emosionalitas yang berdampak dalam bentuk hubungan yang secara positif maupun negatif. Berbagai perubahan yang dialami oleh siswa sebagai akibat masa peralihan yang dialaminya menyebabkan perasaan tidak menentu, gelisah, ragu-ragu, untuk memulai hidup kekal. Perubahan-perubahan tersebut baik secara cepat maupun lambat juga dapat berdampak mempengaruhi kepribadian siswa. Karena menurut Gunarsa (2000:67) ciri-ciri kepribadian siswa ada beberapa bangian yaitu: kegelisahan, pertentangan, Berkeinginan besar untuk mencoba segala hal yang belum diketahuinya, Kecanggungan dalam pergaulan, Ketidakseimbangan dalam keadaan emosi yang labil, mengkhayal dan berfantasi.

Menurut Inoe (2008:6) menyatakan materi ajar adalah segala bentuk materi yang digunakan untuk membantu guru atau instruktor dalam melaksanakan kegiatan belajar mengajar. Menurut Suryosubroto (2009:127) mengatakan materi ajar adalah modal kreatif dan produktif mengadakan materi yang menuntut pemahaman yang tinggi terhadap nilai, konsep, atau masalah aktual di masyarakat serta keterampilan menerapkan pemahaman tersebut dalam bentuk karya nyata. Selanjutnya menurut Dirman dan Juarsih (2014:70) materiajar adalah segala sesuatu yang menjadi isi kurikulum sesuai dengan kompetensi dasar dalam rangka pencapaian kompetensi inti setiap mata ajar dalam satuan pendidikan tertentu. Menurut Brownlee (2011:9)mengemukakan "Keselamatan dalam gereja kata "selamat" dan "keselamatan" biasanya dipergunakan dengan arti keselamatan dari dosa atau neraka, Allah menyelamatkan kita dari dosa(Mat 1:21; Luk 1:77), penghukuman (Yoh 3:17; 12:47), kebinasaan (1Kor 1:18) dan maut (Yoh 5:20; Luk 6:19). Sedangkan Wuwungan (2009:13) mengatakanbahwa "Keselamatan ialah penciptaan kembali (recreation) manusia yang jatuh kembali 'manusia baru' seperti sediakala". Senada dengan pendapat tersebut Jenus (2012:23) mengatakan "Keselamatan adalah tindakan proaktif Tuhan atas manusia. Keselamatan ditentukan oleh Allah, bukan hasil perbuatan manusia atau usaha manusia". Menurut Kakiay (2003:61) mengemukakanbahwa "Keselamatan ialah sikap hati seseorang yang mengakui bahwa Yesus Kristus adalah Tuhan Juruselamat manusia dan melalui Tuhan yesus Kristus manusia akan memperoleh keselamatan dan kehidupan kekal yang dibuktikan dengan kerinduan yang dalam untuk menjadi pengikut Kristus yang setia dan taat kepada-Nya sampai akhir hidup. Sedangkan menurut Ellis (1999:58-65) mengatakan keselamatan adalah: 1). Hati baru (Yeh 38:26). 2). Kelahiran baru (Yoh 3:3; 1 ptr 1:23). 3).Ciptaan baru (2 Kor 5:17). 4). Arah baru (Mat 7:13,14). 5). Pemilik baru (1 Kor 3:16). 6). Ketenangan hati-jiwa baru (Mat 11:28,29). 7). Jalan baru (Yoh 14:6; Kis 4:12). 8). Hidup baru (1 Kor 2:12; 2 Kor 3:L18). Selanjutnya menurut Browning (2008:389) mengemukakan "Keselamatan diberikan Allah kepada seluruh umat manusia 
melalui jalan iman dan injil. Sedangkan menurut Mcelrath dan Billy (1992:69) mengatakan keselamatan adalah hal melepaskan atau menghindarkan dari bahaya. Menurut Senduk dalamGernaida (2008:218) mengemukakan bahwa aspek keselamatan adalah :a. Keselamatan berhubungan dengan penebusan. b. Keselamatan berhubungan dengan rekonsiliasi. c.Keselamatan berhubungan dengan propisiasi. d. Keselamatan berhubungan dengan keselamatan. e. Keselamatan berhubungan dengan pengorbanan. f. Keselamatan berhubungan dengan pengudusan. Selanjutnya keselamatan mempunyai tiga aspek menurut Evans (2004:401): 1). Keselamatan dari hukuman dosa. 2). Keselamatan pembebasan dari kuasa dosa. 3). Keselamatan yang oleh dimuliakan. Sedangkan Menurut Victor (2012:61)mengatakan bahwa: 1). Keselamatan adalah Anugerah.2). Keselamatan adalah Penebusan. 3). Keselamatan adalah Tanggung Jawab. Dibawah ini Paulus akan akan menguraikan dasar Alkitab tentang keselamatan: Efesus 2:8-9; Roma 5:9-10; Kisah Para Rasul 4:12 ; Roma 3:23; Matius 1:21; 1 Yoh 3:5; Mazmur 37:39; Roma 10:10; 2 Tomotius 1:9. Materi Ajar Tentang Keselamatan di SMP Negeri 1 Sipahutar

\section{Pengertian Selamat}

Pada umumnya, selamat diartikan terhindar dari bencana, aman sentosa, sejahterah, tidak kurang suatu apa pun, tidak mendapat gangguan, atau kerusakan. Allah menyelamatkan manusia

\section{Mengapa?}

Mengapa Allah menyelamtkan manusia? Pertanyaan ini muncul karena manusia yang diciptakan dengan sungguh amat baik itu ternyata memberontak kepada Allah. Manusia tidak percaya dan tidak patuh kepada Allah. Manusia tidak menurut perintah Allah. Meskipun demikian, Allah berkenan menyelamtkan manusia karena:a). Manusia berada dalam kondisi tidak selamat. Manusiatelah putus hubungan dengan Allah.b). Dengan kekuatannya sendiri, manusia tidak mampu melepaskan diri dari kondisi tidak selamat itu.

\section{Siapa dan bangaimana?}

Allah yang menghendaki semua orang diselamatkan. Namun, untuk itu, manusia harus menentukan sikap atau pilihan terhadap penyelamatan yang dikerjakan oleh Allah. Meskipun Allah menghendaki semua manusia diselamtkan, tetapihanya manusia yang percaya dan mau menerima penyelamatan Allah yang akan diselamatkan. Bangaimana Allah menyelamatkan manusia berdosa? Melalui Alkitab, kita dapat mengerti cara Allah menyelamatkan manusia, yaitu Allah melibatkan diri-Nya dalam kehdupan manusia. Sejarah penyelamatan Allah berpusat pada tiga peristiwa, yaitu peristiwa bangsa Israel, peristiwa manusiawi Yesus,dan peristiwa Roh Kudus.

3. Penyelamatan yang menyeluruh 
Allah menciptakan manusia dari debu tanah, kemudia Allah menghembuskan nafas hidup kehidungnya; demikianlah manusia menjadi makhluk hidup (Kej 2:7). Manusia memiliki tubuh dan roh. Tubuh dapat diliat oleh mata, sedangkan roh tidak dapat dilihat oleh mata. Dalam hal keselamatan manusia, sering dipersoalkan, yang diselamtkan itu hanya Roh, atau tubuh.

\section{Kapan Waktunya?}

Bertolak dari pengertian tentang hidup kekal seperti yang ditulis dalam Yoh 17:3, hidup kekal itu sudah diterima sejak manusia menerima dan percaya kepada Tuhan Yesus Kristus sebagai utusan Allah untuk menyelamatkan manusia (Yoh 3:16). Keselamatan, hidup kekal, bukan sesuatu yang harus ditunggu-tunggu pada akhir zaman. Sekarang pun manusia bisa mendapatkannya. .

Menurut Hadisubrata (1998:6) mengatakan kepribadian adalah sebagai organisasi yang dinamis. Sistem-sistem psikofisik dalam diri manusia yang menentukan kekhasan perilaku dan pemikirannya atau penyesuaiannya dengan lingkungan. Lebih lanjut mengenai kepribadian Dariyo (2003:116) mengatakan bahwa individu yang memiliki kepribadian yang matang ditandai dengan adanya sikap: 1). Mampu melakukan kontrol diri yang kuat. 2). Memiliki sifat suka menolong orang lain. 3). Berfikir optimis bahwa semua masalah dapat diselesaikan dan ada cara untuk menyelesaikannya. 4). Memiliki dan mampu meningkatkan rasa percaya diri, harga diri dan konsep diri yang positif. 5). Optimis menghadapi masa depan hidupnya.

Sejalan dengan itu Hurlock seperti yang dikutip oleh Syamsu Yusuf (2004:130) kepribadian yang sehat (healty personality) ditandai dengan karakteristik sebagai berikut: 1). Mampu menilai diri secara realistik. Individu yang kepribadiannya sehat mampu menilai dirinya sebagaimana adanya, baik berlebihan maupun kekurangan/kelemahan, yang menyangkut fisik (postur tubuh, wajah, keutuhan dan kesehatan dan kemampuan). 2). Mampu menilai sesuatu secara realistic. Dia tidak mengharapkan kondisi kehidupan itu sebagai suatu yang harus sempurna. 3). Mampu menilai prestasi yang diperoleh secara realistik. Individu dapat menilai prestasinya secara realistic dan mereaksikannya secara rasional. Dia tidak menjadi sombong, angkuh, atau mengalami "superiority complex", apabila memperoleh prestasi yang tinggi dalam hidupnya, apabila dengan kegagalan dia tidak mereaksikannya dengan frustasi tetapi dengan sikap optimis (penuh harapan). 4). Menerima tanggung jawab. Individu yang sehat adalah individu yang bertanggung jawab. Dia mempunyai keyakinan terhadap kemampuannya untuk mengatasi masalah-masalah kehidupan yang dihadapinya. 5). Kemandirian (autonomi). Individu memiliki sikap mandiri dalam cara berpikir dan bertindak, mampu mengambil keputusan secara konstrukstif dengan norma yang berlaku dilingkungannya. 6). Dapat mengontrol emosi. Individu yang merasa 
nyaman dengan emosinya. Ia dapat menghadapi situasi frustasi, depresi atau stress secara positif dan konstruktif, tidak deskruktif (merusak). 7). Berorientasi tujuan. Setiap orang mempunyai tujuan yang ingin dicapainya. Namun, dalam merumuskan tujuan ada yang realistic ada juga yang tidak realistik, pribadi yang sehat dapat merumuskan tujuannya berdasarkan pertimbangan secara nyata (rasional), tidak dasar atas paksaan dari luar. Dia berupaya mencapai tujuan tersebut dengan cara mengembangkan kepribadiannya (wawasannya) dan keterampilannya. 8). Berorientasi keluar. Individu yang sehat memiliki orientasi keluar (ekstrover). Dia bersikap respek, empati terhadap orang lain mempunyai kepedulian terhadap situasi atau masalah-masalah dilingkungannya dan bersifat fleksibel dalam berpikir. Penerimaan sosial. Individu dinilai positif oleh orang lain, mau berpartisipasi aktif dalam kegiatan sosial, dan memiliki sikap bersahabat dalam berhubungan dengan orang lain. 9). Memiliki filsafat hidup. Dia mengarahkan hidupnya berdasarkan filsafat hidup yang berakar dari keyakinan agama. 10). Bahagia. Individu yang sehat situasi kehidupannya diwarnai kebahagiaan.

Berdasarkan uraian diatas maka dapat disimpulkan bahwa kepribadian yang matang ditandai dengan indikator sebagai berikut: a). Memiliki kontrol diri yang baik terhadap pengaruh negatif yang datang dari luar dirinya (Efs 3:13-15). b). Memiliki sifat suka menolong orang lain ( Gal 5:14). c). Mampu berpikir positif dalam menyelesaikan semua masalah yang ada dalam hidupnya (Rom 12:12). d). Memiliki rasa percaya diri dan konsep diri yang positif dalam hidupnya (Ef 3:12). e). Bersikap optimis dalam menghadapi masa depan hidupnya (Mzm 37:37). f). Memiliki pemahaman dan penerimaan diri dengan baik tanpa merasa berbeda dengan dan malu terhadap orang lain (Ams 24:14). g). Dapat menyesuaikan diri dan menjalin persahabatan dengan baik terhadap orang lain tanpa menimbulkan sikap permusuhan (Luk 6:27). h). Memiliki sifat kreatif dan ekspresif dalam kehidupannya serta mendasarkan semua tindakannya pada norma dan etika yang berlaku dalam lingkungannya (1ptr 1:22). i). Dapat menerima semua pengalaman yang terjadi dalam hidupnya secara positif dan tidak mudah putus asa dalam apabila mengalami pengalaman yang mengecewakan (Ib 12:3).

Gunarsa (2000:67) menagatakan secara umum ada beberapa ciri kepribadian yang ditunjukkan oleh siswa, yaitu:1). Kegelisahan . 2). Pertentangan 3). Berkeinginan besar untuk mencoba segala hal yang belum diketahuinya .3). Kecanggungan dalam pergaulan. 4). Ketidakseimbangan dalam keadaan emosi yang labil. 5). Mengkhayal dan berfantasi.n6). Kecenderungan membentuk kelompok. Sagala (2003:95-100) mengatakan penadapat menganai faktor yang mempengaruhi kepribadian pada pokoknya dapat dibagi kedalam empat aliran, yaitu:1). Nativisme 2). Naturalisme. 3). Empirisme. 4). Konvergensi. Selanjutnya Gunarsa (2000:24) mengatakan bahwa faktor yang mempengaruhi kepribadian indivdu dapat dibagi atas dua kelompok utama, yaitu: 1). Faktor yang berasal dari 
dalam diri individu atau faktor endongen.2). Faktor yang berasal dari luar diri individu atau faktor eksogen: a). Lingkungan keluarga. b). Lingkungan masyarakat. C). Lingkungan sekolah . Menurut Harianto (2012:69) mengatakan Orangtua memiliki peranan yang sangat penting bagi pembentukan kepribadian anak. Untuk membentuk kepribadian anak ke arah yang positif orangtua harus dapat menciptakan suatu keadaan dimana anak dapat berkembang. Menurut Gunarsa (2000:125) adapun usaha-usaha yang pembentukan kepribadian yang perlu dilakukan oleh oragtua adalah: a). Pemeliharaan hubungan baik antara orangtyua dengan anak. b). Memberikan kesempatan yang cukup banyak untuk berbicara antara orangtua dan anak dengan pengertian bahwa para anak memperoleh hak mengemukakan pendapat dan pandagan mereka secara bebas. c). Memberikan kesempatan untuk mengembangkan inisiatif anak dan kesempatan untuk berekperimen dalam batas tertentu .d). Orangtua harus memupuk kepercayaan diri anak dan perasaan aman untuk dapat berdiri dan bergaul dengan orang lain.

\section{METODE PENELITIAN}

Populasi dalam penelitian iadalah seluruh siswa kelas VII SMP Negeri 1 Sipahutar sebanyak 150 0rang. Sampel dalam penelitian $25 \%$ dari 150 orang = 36. Penelitian ini menggunakan angket tertutup .Untuk mengukur penguasaan materi ajar digunakan tes bentuk pilihan berganda dengan pilihan jawaban empat option (a,b,c,d). Uji coba dilakukan kepada 30 orang kelas VII SMP N 1 Sipahutar diluar responden. Untuk mengetahui apakah terdapat hubungan signifikan antara variabel $\mathrm{x}$ digunkana uji t dengan rumus yang dikemukakan oleh Sudjana (1992:380) sebagai berikut :

$$
t=\frac{r \sqrt{n-2}}{\sqrt{1-r^{2}}}
$$

Melakukan uji pengaruh dengan rumus $\mathrm{r}^{2}$ sebagaimana dikemukakan oleh Sudjana (1992:92) sebagai berikut:

$$
\Gamma^{2}=100 \cdot \Gamma_{\Gamma^{2}} \%
$$

Untuk mengetahui derajat pengaruh variabel $\mathrm{x}$ terhadap variabel $\mathrm{y}$, dilakukan perhitungan persamaan regresi sederhana dengan rumus $\hat{Y}$ sebagaimana dikemukakan Sudjana (1992:315) sebagai berikut:

Dimana:

$$
\hat{Y}=a+b X
$$

$$
a=\frac{\left(\sum Y\right)\left(\sum X^{2}\right)-\left(\sum X\right)\left(\sum X Y\right)}{n\left(\sum X^{2}\right)-\left(\sum X\right)^{2}} \quad b=\frac{n\left(\sum X Y\right)-\left(\sum X\right)\left(\sum Y\right)}{n\left(\sum X^{2}\right)-\left(\sum X\right)^{2}}
$$


Mencari nilai $\mathrm{F}$ hitung dan mengkonsultasikannya denga $\mathrm{F}$ tabel. Untuk melihat signifikansi pengaruh, dengan rumus sebagaimana dikemukakan Sudjana $(1992: 332)$

$$
F=S^{2} \text { reg } / S^{2} \text { res }
$$

\section{HASIL PENELITIAN}

Pengujian hipotesis menunjukkan bahwa hipotesis yang diajukan dalam penelitian ini diterima yang mengungkapkan terdapat pengaruh yang positif dan signifikan antara Penguasaan Materi Ajar Keselamatan terhadap Kepribadian Siswa Kelas VII SMP Negeri 1 Sipahutar Kabupaten Tapanuli Utara Tahun Pembelajaran 2019/2020 dengan koefisien determinasi sebesar 36,24\% dan $\mathrm{F}_{\text {hitung }}$ $=20,30>\mathrm{F}_{\text {tabel }}=4,13$. Hasil pengujian hipotesis menunjukan terdapat pengaruh yang positif dan signifikan antara Penguasaan Materi Ajar Keselamatan terhadap Kepribadian Belajar Siswa Kelas VII SMP Negeri 1 Sipahutar. Kecamatan Sipahutar Kabupaten Tapanuli Utara Tahun Pembelajaran 2019/2020 Hal ini berarti hipotesis yang dikemukakan dalam penelitian ini dapat diterima.

\section{PENUTUP}

Berdasarkan uji pengaruh diperoleh koefisien determinasi $r^{2}=36,24 \%$ dan $F_{\text {hitung }}>F_{\text {tabel }}$ sebesar 20,30>4,13 pada taraf $=0,05$. Hasil tersebut memberi kesimpulan terdapat pengaruh yang positif dan signifikan antara Penguasaan Materi Ajar Keselamatan terhadap Kepribadian Belajar Siswa Kelas VII SMP Negeri 1 Sipahutar. Kecamatan Sipahutar Kabupaten Tapanuli Utara Tahun Pembelajaran 2019/2020.

\section{DAFTAR PUSTAKA}

Alkitab: Lembaga Alkitab Indonesia

Brownlee, Malcolm. 2011. Tugas Manusia Dalam Dunia Milik Tuhan. Jakarta: BPK Gunung Mulia

Dariyo, Agoes. 2003. Psikologi perkembangan dewasa muda. Jakarta: Casindo

Ellis, Dw. 1999. Metode Penginjilan. Jakarta Yayasan Komunikasi Bina Kasih

Evans, Tony. 2004. Hal Yang Paling Utama Dalam Kehidupan Rohani. Batam Gospel Press

Gunarsa, Singgih D. 2000. Psikologi remaja. Jakarta: BPK Gunung Mulia 2003. Psikologi perkembangan. Jakarta:BPK gunung Mulia , 2003. Psikologi untuk keluarga. Jakarta: BPK Gunung Mulia

Hadisubrata M.S. 1998. Mengembangkan Kepribadian anak. Jakarta :S BPK Gunung Mulia

Harianto. 2012. PAK dalam Alkitab dan Dunia Pendidikan masa kini. Yogyakarta: Andi

Inoe. 2008. Materi Ajar. Jakarta Andhy Sastera 
Junimen, Jenus. 2012. Dapatkah Keselamatan Orang Percaya Hilang. Yogyakarta ANDI

Kakiay, Ferry.2003. Teologi GBI. Kapernaum PeMOI Publising House

Mathias, Mcelrath. 1992. Ensiklopedia Alkitab Praktis. Bandung Lembaga Literatur Baptis

Tobing, Victor. 2012. Apakah Anda Selamat? Soteriologi. Yayasan Penginnilan dan Penelaahan Alkitab Sumatera Utara.

Sagala, Syaiful. 2003. Konsep dan makna pembelajaran untuk membangun memecahkan problematika belajar dan mengajar. Bandung. CV. Alfbeta

Senduk. 2008. Guru Teolog dan Pemimpin Yang Membagi Hidup. Seminari Bethel dan Departemen Media Litbang BPH

Sudjana. 1992. Metode Statistika. Bandung : Tarsito.

Suryosubroto. 2009. Proses belajar mengajar di sekolah. Yogyakarta Rineka Cipta

Syamsuyusuf, Dr. 2004. Memahami sesama kita. Yogyakarta: gandum mas

Wuwungan. 2009. Bina Warga Bunga Rampai Pembinaan Warga Gereja. Jakarta BPK Gunung Mulia 